\title{
Europe-Mughal India-Muslim Asia: Circulation of Political Ideas and Instruments in Early Modern Times
}

\author{
Corinne Lefèvre
}

\section{Introduction}

The purpose of this essay is to consider Mughal state-building and ideology in a wider geopolitical context than has generally been the case. By wider geopolitical context, I mean not only Europe, but also what I would call the Asian-Islamicate ecumene-a region that stretched from Istanbul to Aceh and housed a number of powerful polities in early modern times-for it is my contention that the processes of political and cultural transfer that took place between Asia and Europe in the sixteenth-eighteenth centuries should be examined side by side with those transfers that took place within Asia and within Europe, in order to provide a fuller and more balanced picture of the issue. From the restricted point of view of the Mughal empire, which is my area of expertise, this means tackling a number of questions, such as: what was the political horizon of the Mughals, what did they know about the political experiments that were carried out in early modern Europe and Muslim Asia, and what were the elements of these experiments, if any, that were deemed adaptable in the Indian context? Conversely: what were the perceptions of the Mughal polity in early modern Europe and Asia, and to what extent and to which states did it act as a model or, on the contrary, as a foil? Because of space limitations, I will focus here on the first set of questions.

These first questions are all the more interesting because they point to a significant and lasting feature of the historiography of the Mughal state, i.e. its presentation as an exclusively Indian phenomenon. Contrary to what this "Indocentric" view suggests, the empire founded by Bābur (ruled 1526-1530) cannot be reduced to an extractive machine feeding itself with agrarian surplus and working in quasicomplete isolation from the rest of the early modern world. Quite the opposite: the

C. Lefèvre ( $ه)$

Centre d'Études de l'Indes et de l'Asie du Sud, École des Hautes Études en Sciences Sociales, 190-198 avenue de France, 75244 Paris Cedex 13, France

e-mail: co.lefevre@gmail.com 
seventeenth century whose beginning roughly coincided with the accession to the throne of Jahāngīr (ruled 1605-1627), witnessed the development and diversification of the European presence in the subcontinent on an unprecedented scale, as well as a significant increase in exchanges with the West. Concurrently, and as may be seen, for instance, from the multi-ethnic composition of the Mughal nobility, the empire attracted elites in search of employment from all over the Asian-Islamicate ecumene. And yet, the impact of those multi-directional exchanges on the political genesis and evolution of the Mughal state has not, until now, received the attention it deserves.

This holds particularly true for the question of the political-cum-cultural impact of the European presence on the Mughal elite, most authors concentrating on the economic changes brought by the Western trade companies (Das Gupta 1979; Prakash 1985) or on Said-inspired analyses of European writings on Mughal India (Teltscher 1995). The reason often advanced for this cursory treatment is the scarcity of Indo-Persian texts dealing with Europeans - this very scarcity being usually interpreted as "the" sign of the Mughals' lack of interest for things Western (Pearson 1987: 53). While Mughal writings on the West can hardly be compared in quantity to the massive European production documenting the encounter with the empire, there are nevertheless - as pointed out more recently by a number of historians and art historians (see below for references) - a number of texts, as well as iconographic materials that shed some light on the politico-cultural impact of the European presence and on some interesting cases of circulation and transfer in this domain.

Even though the relation between pre-colonial India and European powers is a research topic that is today far from being exhausted and needs to be pursued, the great importance it has been given since colonial times has led to the neglect of the relations connecting the Mughals with another set of polities geographically and culturally far closer to them (Ottomans, Safavids, Uzbeks, sultans of Aceh). As a matter of fact, the historiography dealing with these relations has been largely confined to diplomatic studies of traditional workmanship (Islam 1970; Farooqi 1989), and to a handful of structuralist comparisons informed by the old orientalist paradigm (Ali 1992; Moosvi 2002). Besides, on the margins of Mughal historiography proper, a number of scholars have dealt with the circulation of elites and analysed their role in the transmission of political ideas within the Asian-Islamicate ecumene (Subrahmanyam 1992; Wormser 2009). Finally, the last two decades have seen the publication of quite a few essays examining jointly the ideological discourses produced by different dynasties of Muslim Asia (Dale 1998; Necipoğlu 1993; Moin 2010).

As shown by this brief survey, research connecting the political and cultural history of the Mughal empire with that of the contemporary states of Europe and Muslim Asia has, until quite recently, remained largely fragmentary. And yet, as advocated by the editors of this volume and a number of other scholars, the histories of the various components of the early modern world have a lot to learn from each other, the early modern times being a period of increased contact between the four parts of the world, as well as a moment of intense political rivalry both within Europe and Muslim Asia and between them. In this highly competitive context, the solutions worked out by a dynasty in such important fields as taxation, relations between ruler and nobility, or management of religious plurality came to constitute 
as many models, which could possibly influence the choices made by one or more of its rivals. However, not every route that ran across the political space of early modern Europe and Muslim Asia was equally busy: as this essay will demonstrate, some of them proved dead ends, while others developed into highways.

\section{European Political Culture and History in Mughal India}

I will start, then, with a re-examination of contemporary primary sources (mostly from the seventeenth century) documenting Mughal interest for things Western in the politico-cultural sphere. If one turns first to the European writings and records of the time, one comes across a series of passages showing Mughal monarchs and amīrs enquiring about the political situation of one or more European countries. One of the most interesting comes from the pen of Edward Terry, chaplain to Sir Thomas Roe, the first English ambassador sent to the Mughal court in the mid1610s. In the course of his Voyage to East-India, Terry describes the reaction of Jahāngīr to Mercator's Atlas in the following way: "The Mogul feeds and feasts himself with this conceit, that he is Conqueror of the World; and therefore I conceive that he was troubled upon a time, when my Lord Ambassador presented him with Mercator's great book of Cosmography that described the four parts of the world. The Mogul at first seemed very much taken with it, desiring presently to see his own territories, which were immediately shown to him; and then [...], finding no more to fall to his share, [...] seemed to be a little troubled, yet civilly told the Ambassador, that neither himself, nor any of his people, did understand the language in which that book was written, and therefore returned it unto him again" (Terry 1777: 350-351).

These few lines are particularly interesting because they clearly associate geographical knowledge with political power. Following this is the idea that the monarch's limited interest in the Atlas, i.e. in the world beyond his kingdom, derived from a denial of the supposed objective geographical reality it depicted: in other words, Jahāngīr sent the Atlas back because he refused to be confronted with the relativity of his power and to revise his claims accordingly. Although the bias underlying such an explanation is quite obvious, these lines, as well as Roe's account of the same event, have often been used by modern scholars as a proof of Mughal indifference to the wide world in general, and to Europe more specifically. However, as argued by Ahsan Qaisar three decades ago (Qaisar 1982: 148-149), Roe and Terry may be contrasted on this subject with other contemporary European writings showing that geographical artefacts such as globes, maps and atlases were actually in demand at the Mughal court. Pointing towards the same direction is the existence of a mid-seventeenth century atlas (Habib 1980), as well as the specific role terrestrial globes of European inspiration came to play in imperial allegorical painting.

Reference here is to the works of Ebba Koch and Sumathi Ramaswamy who have shown how, starting with Jahāngīr, the terrestrial globe penetrated the 
allegorical portraits of the monarch, where it came to stand as an exclusive imperial attribute and a symbol of world domination (Koch 1997: 139-141; 2009: 330-333; Ramaswamy 2007). This was not, however, a case of straightforward adoption: having fully grasped the potentialities of this imported cartographic language, the Mughal artists deployed the globe-form in support of the agenda of their patron, subverting at the same time the Europe-centred mapping of the Earth that originally underlay it. As a matter of fact, a remarkable feature of these Mughalised globes is that they centred on India, which also assumed larger dimensions than in their European counterparts. The specific example of the globe points more generally to an area where the European impact on Mughal political culture can hardly be denied, i.e. the visual propaganda in the service of the empire. As shown by a number of art historians such as Gauvin Bailey and Ebba Koch (Bailey 1998; Koch 2001), Mughal borrowings were particularly important in this domain, ranging from the appropriation of a whole visual language (the allegorical manner) to that of isolated motifs (putti, portraits of Jesus and Mary, etc.). As in the case of the globe, however, the European-Christian elements were extracted from their original context of production and given a new garb or meaning that best fitted their redeployment as instruments of the Mughals' legitimacy. While the Mughals were themselves heirs to a Tīmūrid tradition that particularly valued the visual representations of power, the European visual strategies they encountered significantly influenced the political vocabulary they elaborated to depict themselves and their achievements.

In contrast to the evidence of transmission provided by the pictorial records of the imperial atelier stands the relative dearth of actual references to Europe, particularly to its political history and culture, in the Indo-Persian writings produced before the mid-eighteenth century. In the last decade, however, two publications by Simon Digby and Sanjay Subrahmanyam have qualified this scarcity through the analysis of texts that had so far escaped the attention of historians, possibly because of their too-heavy reliance on official court chronicles (Digby 1999; Subrahmanyam 2005). However, the conclusions they draw from these materials differ rather substantially. Digby focuses, for his part, on two texts in which Europe is seen either through the lens of older and obsolete Arabo-Persian geographical lore or as a reservoir of exotic marvels - the two perspectives sometimes coexisting, as in the case of the Ma'lümät-ul-äfāq (Knowledge of the horizons) written by the Mughal official Amīn-ud-dīn Khān in the second half of the seventeenth century. This leads Digby to conclude that Mughal elites generally had no curiosity about the outside world and were unable to grasp contemporary information about it in the few geographical works they produced. Whilst acknowledging the existence of fanciful accounts of Europe such as those presented by Digby, Subrahmanyam underlines the fact that these partook of a shared early modern attraction to wonders-referred to as ' $a j \bar{a}$ ' $i b$ - $u$-ghara $\bar{a}^{\prime} i b$ in Persian and as mirabilia in Latin, an attraction which surfaces as well in contemporary accounts of the East and West Indies. Furthermore, "just as is the case with the Europeans, the presence of a register of "wonders" in the Indo-Persian corpus does not in fact preclude the simultaneous accumulation of political, economic and other materials 
in a far more matter-of-fact tone" (Subrahmanyam 2005: 80). As an illustration of this point, he calls attention to a little-known work completed in 1606 by another Mughal official by the name of Țāhir Muhammad. Entitled Rauzat-ut-țāhirīn (The garden of the immaculate), the text is a general history of the oriental Muslim world and has a chapter devoted to "the wonders and curiosities of the ports and islands" surrounding Bengal, in which may be found a description of Portugal. True to the general title of the section, wondrous tales are well represented in the account, but they appear side by side with much more reliable information about contemporary events which, the author writes, he had gathered during his mission to Goa at the end of the 1570s. Among such information, pride of place is given to the fateful campaign of the Portuguese monarch Dom Sebastião (ruled 1557-1578) against the kingdom of Morocco, the account of which, notwithstanding some inaccuracies and an underlying Muslim bias, perfectly matches the criteria of political report, and clearly does not belong to the repertoire of wonders.

The corpus brought to light by Digby and Subrahmanyam certainly gives a better idea of the dual regime (wondrous/factual) that underlay the recording of the Mughal perceptions of Europe; yet, it does not say much about the central question raised at the beginning of this essay. In this perspective, I would like to draw attention to a couple of works composed by two eminent figures who flourished during the reigns of Akbar (ruled 1556-1605) and Jahāngīr. The first and best known of them is the Jesuit Spaniard Jerónimo Xavier (d. 1617), who headed the third Jesuit mission to the Mughal court from 1595 to 1615; the second is the Mughal courtier and scholar 'Abd-us-Sattār ibn Qāsim Lāhaurī (d. after 1619). Under the instructions of emperor Akbar, the two men came to constitute some kind of a translation team whose task was to familiarise the Mughal elite with the GrecoRoman and Christian foundations of contemporary European culture. This implied an intensive linguistic training, to which both men submitted: in their writings, they indicate how they respectively learnt how to read and write Persian (for Xavier) and Latin (for Sattār).

The best known results of this collaboration are a series of catechistic works written in Persian and including Lives of Jesus (Mir'ät-ul-quds or Mirror of Holiness, 1602) and of the Apostles (Dāstān-i aḥwāl-i hawāriyyān or Account of the Life Episodes of the Apostles, 1605-1607). While these texts have long been objects of interest for specialists of Jesuit studies (Maclagan 1932; Camps 1957), the recent publication of a hitherto unknown chronicle by Sattār-the Majālis-i Jahāngīrì (1608-1611), which, among other things, documents the Mughal viewpoint on the religious debates held at court ('Abd-us-Sattār 2006) — has led to a reconsideration of contemporary Muslim-Christian discussions, as well as of the exact nature of the collaboration between Sattār and Xavier (Alam and Subrahmanyam 2009). Much more relevant for the present purpose is, however, the production of two other works whose ambition was much more secular in nature. Completed in 1603 by Sattār, the earliest one is a history of the great kings and philosophers of Antiquity entitled Samarat-ul-falāsifa (The fruit of philosophers); the second-the $\bar{A} d \bar{a} b$-us-saltanat (The duties of kingship)—is a mirror for princes dedicated by Xavier to Jahāngīr in 1609. Neither of these texts 
has been edited so far, and the following analysis is based on a preliminary survey of two manuscript copies preserved in London. ${ }^{1}$

In the preface to their respective works, both authors underscore the originality, within the Indian context, of the information they are about to reveal to their readers, highlighting by the same token their own role as cultural brokers. In the first pages of the Samarat-ul-falāsifa, Sattār thus writes that he was ordered by Akbar "to learn the European language (zabān-i firangī), to inquire the secrets of this people and the affairs of the sultans of this group as well as to render into Persian what Greek and Latin philosophers (hukamā-yi yünān-zamīn wa latin) had said in their books, in order to reveal what had so far remained hidden because of the foreignness of the language, the unavailability of a translator and the distance [between Europe and India]" (BL, MS. Or. 5893: 5).

He then goes on to explain how he learnt Latin in six months with the help of Jerónimo Xavier. In his own preface, the latter similarly underlines the scarcity of Western books in India and the difficulty of accessing them for the Persianspeaking community; this is in contrast to his own knowledge of both Western literature and the Persian language, which allows him to present Jahāngīr with the gist of European political wisdom (SOAS, MS. 7030, 4r-v). While Xavier openly boasts here of his achievement and implicitly compares it to the advice offered by Aristotle to Alexander or by Seneca to Nero (ibid.: 3v), the preface to his Mir'ät-ul$q u d s$ shows that he was actually aware that his was only a contribution to the much more ambitious project of cultural "translation" undertaken by the Mughals (Abdus-Sattār 2006: xl) - a project that also included the rendition in Persian of Sanskrit texts such as the Mahäbhärata, and whose universal scope was equally noted by Sattār, who mentioned Akbar's urge to know "the secrets of the religions and the affairs of the monarchs of every country" (BL, MS. 5893: 4). The results of both these enterprises of knowledge transfer from Europe to Mughal India are, as could be expected, texts endowed with a fair degree of hybridity when language, form and contents are considered together. This comes out rather clearly when one examines their general structure or the diversity of the traditions they drew upon.

The Samarat-ul-falāsifa is structured along both chronological and biographical lines. It has three main parts which successively deal with the Roman kingdom (753-509 в.с.), Ancient Greece until the reign of Alexander the Great (356-323 B.C.), and the time period surrounding the birth of Jesus; this general progression is, however, broken at several points by temporal or spatial leaps, an example of

\footnotetext{
${ }^{1}$ The British Library has a nineteenth-century copy of the work of Sattār (hereafter BL, MS. Or. 5893), which bears the slightly different title of Samarat-ul-faläsifa or Evening story of the philosophers. Of the six other known manuscripts of the text (sometime also entitled Ahwäl-i Firangistän or Events of the land of the Franks), three are preserved in India, two in the United Kingdom, and one in Iran. The copy of the Ādāb-us-saltanat preserved in the School of Oriental and African Studies (hereafter SOAS, MS. 7030) dates from 1609; the Casanatense Library of Rome holds the only other known copy, which was similarly completed in 1609 . For two recent overviews of these works, see Alam and Subrahmanyam (2009: 472-475) and Sidarus (2010). I am grateful to the latter for having given me access to his paper before publication.
} 
which will be examined below. Within each of the chapters are included biographical accounts of the great men of the age (legislators, philosophers, poets, etc.) along with some of their sayings. This is in perfect consonance with Sattār's main source for his work, which he mentions in the preface (BL, MS. 5893: 7): the chronicles or Summa Historialis of Saint Antoninus of Florence (1389-1459), of which Akbar actually owned a copy (Bailey 2000: 385). In this respect, the Dominican archbishop was himself following the model initiated by his coreligionist Vincent of Beauvais (approx. 1190-1264), who was the first universal chronicler of medieval Europe to mix historical discourse with bio-hagiographies and anthologies in his Speculum Historiale (Walker 1933: 107-108; Paulmier-Foucart 2004: 84-92). The adoption by Sattār of such a structure must have been all the more easy since it echoed that of many Indo-Persian chronicles which bore the simultaneous imprint of the two classical genres of tärīkh (history) and tazkira (biography). The general organization of the Samarat calls for two further remarks. One is about the quasi-complete absence of the high Roman Empire, which is only touched upon in relation to the events surrounding the birth of the Christ. The other concerns the organisation and contents of the second part: while its title promises the reader all the truth about Greece (Krisiyya), the chapter actually proceeds with an account of the Achaemenid empire, starting with its founder Cyrus the Great (approx. 559-529 в.с.) and ending with Artaxerxes III (approx. 425-338 B.C.), at which point Alexander-and, beyond him, Greece-becomes the focus of the story. This is not to say that the second part does not deal with Greece at all, since each sub-heading contains biographical notices of men such as Thales, Solon, Democritus, or Aristotle, which, in the latter's case, actually constitutes almost the whole of the account of Artaxerxes. Even though the choice by Sattār of the Achaemenid prism certainly derives from his adherence to the Western scheme of the succession of empires as exemplified in the Summa Historialis, ${ }^{2}$ it takes on an additional dimension when one considers the identity of his patron, for whom the Achaemenids clearly constituted an imperial model.

If one now turns to the general structure of the Ādäb-us-saltanat, what is most striking at first glance is its outward resemblance to that of Tīmūrid and contemporary Mughal mirrors for princes. It typically opens with a chapter in praise of God, the Lord of all, and on the importance of divine worship ("on the respect due to God")—a chapter whose length is, however, greater than is usually the case (SOAS, MS. 7030: 9v-61a). This is followed by two chapters devoted to "the reformation of the emperor (ișläh-i bādshāh)" and to "the guidance and instruction of officers (hidāyat wa tarbiyat-i 'uhdadārān)". This successive focus on the person of the emperor and his relations with the political elite is also traditional, and may be found only a couple of years later in the Mau'iza-i Jahāngìri or Admonition to Jahāngìr. Dedicated to the monarch by the Iranian émigré Bāqir Khān in 1611, the text is composed of two parts dealing with "the exhortation of the emperors" and

\footnotetext{
${ }^{2}$ For the origins of this scheme in Greek historiography, see Momigliano (1982).
} 
"the admonition of subordinates and peers" (Bāqir Khān 1989). Finally, the central topic of the fourth and last chapter of the $\bar{A} d \bar{a} b$-us-saltanat - the love and protection due to the subjects-echoes another common preoccupation of the Indo-Persian authors of mirrors for princes. Its best known symbol is probably the "circle of justice", according to which the prosperity of the king and the kingdom ultimately derives from the prosperity of the subjects. If the structure of Xavier's mirror is then very much akin to that of Mughal treatises of government, the origin and nature of the numerous anecdotes the Jesuit uses to illustrate his general principles differ to a great extent from what is usually found in the latter texts. Whereas the repertoire of Indo-Persian authors traditionally included stories taken from Sassanid and classical Islamic history and, less frequently, from the more recent Indo-Muslim past, Xavier's anecdotes derive for the most part from Biblical and Classical history-a point that leads me to the more general question of the sources used by Sattār and Xavier in their works.

Sattār is probably the most explicit in this regard: besides the Summa Historialis of Antoninus already mentioned, he refers in his preface to his use of the Bible (injil) and other books without, unfortunately, providing further details about them. Although Xavier does not specify the materials on which he relied for his work, they most certainly included the ones indicated by Sattār. Moreover, as he himself points out, he benefited from the knowledge acquired during a life dedicated to "the study of the books of prophets and scholars of the past (mutāla'a-i suhuf-i paighämbarān wa dānishwārān-i pishīn)". There is a hint here of the extensive scholastic culture every Jesuit was supposed to possess and of which the Summa Theologica by Thomas Aquinas (approx. 1225-1274) — who is referred to in the same folio (SOAS, MS. 7030: 4r) —was one of the masterpieces. Finally, there is one part of the $\bar{A} d \bar{a} b$ for which Xavier explicitly indicates his source: the conclusion of the book, he writes at different points in the text (ibid.: 9r, 274v, 275v, 286r), is an abridgement of the advice given by Maecenas (70-8 B.C.) to the first emperor of Rome, Caesar Augustus (ruled 27 B.C.-14 A.D.). Although no author's name or title is given, the reference is clearly to the 52nd book of Cassius Dio's (d. after 229) Roman History, which is almost entirely taken up by the aforementioned advice.

If both the Samarat-ul-faläsifa and the Ādāb-us-saltanat were, then, mostly the result of the transmission of multilayered Western lore into Mughal India, there is interesting evidence in the former work that this process of translation was not carried out without raising a number of questions on the receiving side. This is evident from the few pages Sattār devotes to some episodes of the history of Spain (BL, MS. 5893: 48-56), which is here not referred to as such, but as "the peninsula of al-Andalus (jazira-i ündalus)". Perhaps prompted by a discussion with Xavier about his homeland, the Spanish digression is inserted at the beginning of the section on Greece and may be divided into two parts. Relying mostly on medieval Arab geographers, ${ }^{3}$ the first starts with the Greek colonisation of the peninsula

\footnotetext{
${ }^{3}$ For the pre-Islamic history of Spain as seen by Arab geographers and historians, see Picard (2003).
} 
under Alexander the Great and ends with the Muslim conquest of Toledo at the time of the Visigothic (wisiq) king Roderic, in 711; the crux of the story here is Roderic's seizure of the famous Table of Solomon, whose power had until then protected the kingdom from foreign invaders. ${ }^{4}$ At this point in the account, Sattār stops and writes that the European priest ( $p \bar{a} d r \bar{l}-y i$ firang, i.e. Jerónimo Xavier) gave him another version of the story, which constitutes the second part of the Spanish digression. In contrast to the first, this provides dates according to the Christian rather than to the Hijri calendar, as well as transliterations of the exact names of the European protagonists. It starts with the traditional explanation of the loss of Toledo as recorded in Western medieval sources: as Xavier himself explains in his $\bar{A} d \bar{a} b$ (SOAS, MS. 7030: 140v-141v), it was all because of the treason of Julian, count of Ceuta, who avenged himself for Roderic's insult (he had seduced Julian's daughter) by giving the Muslims considerable help. The account that follows of the eleventhcentury reconquista of Toledo at the hands of Alphonse VI of León and Castile (1085) similarly derives from European materials. It is Sattār, however, who has the last word: since this time, he laments, not a single Muslim may be found in the country. Sattār's Spanish digression is particularly interesting for two reasons. First, in contrast to the "translation" logic that lay at the root of the Samarat, he here juxtaposes side by side Arabo-Muslim and European-Christian versions of the same event, while refraining from openly favouring one over the other (probably because both put the blame on Roderic, although for different reasons). Second, these pages constitute one of the very few glimpses the Samarat gives its reader into more recent Western history. The only other one is situated at the end of the preface where Sattār provides a very brief geopolitical sketch of contemporary Europe: Italy, Spain, France, Germany and Castile are mentioned in turn without, however, further details (BL, MS. 5893: 9).

This brings me to the more general question of the presence and role of contemporary Europe in the two works under analysis. As has just been mentioned, it was minimal in the case of the Samarat, where contemporary Europe was first and foremost a reservoir to be tapped for information on Western ancient history and lore-the actual focus of the work. Still one may wonder why, so far as is known, the Mughals' universal curiosity did not prompt them to commission some kind of continuation to the Samarat, or why the Jesuits did not think it necessary for them to have one. A closer look at the $\bar{A} d \bar{a} b$-us-saltanat, and more specifically at the anecdotes it includes, certainly helps to clarify the last point to some extent. In this perspective, the brief piece of advice Xavier gives to the reader in the final lines of the preface is particularly illuminating: because the people mentioned in his book do not hail from India, he writes, he decided to remove their names from the body of the text $(\mathrm{matn})$ in order to facilitate the comprehension of its general principles, and to indicate them instead in the margin (hâshiya) so that the credibility of their words

\footnotetext{
${ }^{4}$ BL, MS. 5893: 49-51. For a similar account by a fifteenth-century North African geographer, who was himself relying on a number of predecessors such as al-Idrīsī (d. approx. 1165), see alḤimyarī (1938: 10-11, 157-159).
} 
might not be doubted (SOAS, MS. 7030: 9r-v). In other words, the true objective of the $\bar{A} d \bar{a} b$ seems to have been primarily to arouse Jahāngīr's interest in the moral principles of Christianity as applied to politics, and secondarily only to inform him about contemporary Europe.

For all that, it is nonetheless significant that among the great men mentioned by Xavier as exempla, figures from Biblical and Classical history are far better represented than personalities of late medieval or early modern times. While the possible reliance of the Jesuit on the Summa Historialis of Antoninus may partly account for this imbalance, his own Navarrean origins and his close relationship with Goa explain to a large extent the Iberian identity of the vast majority of the most recent political figures he refers to. Taking the sixteenth century as an example, the only exception to this scheme is the French Valois king Francis I (ruled 1515-1547), Philip II of Spain (ruled 1556-1598) being by far the most often mentioned. Because Philip II is also the European monarch with whom the Mughals had, by that time, established the closest relations, it is worth pausing for a while on the aspects of his personality and policy Xavier thought fit to publicise in the eyes of his Indian audience.

So far, I have been able to identify six anecdotes relating to the dispensation of the Habsburg who, in the Persian text, is generally referred to as "the emperor of Spain" (bādshāh-i ispāniyya). These anecdotes are unequally distributed across the $\bar{A} d \bar{a} b$, all of them being found in the third and fourth chapters (SOAS, MS. 7030: 198v-199r, 204v, 229v, 248r-v, 259r, 265v-266r). All in all they illustrate two characteristics of Philip II's government as seen by Xavier. First, the ability of the monarch to gather information on every possible individual: such knowledge endows him with the necessary foresight to pick up the right men for advice and administration as well as to anticipate his enemies' moves. Second, Philip II is portrayed as a ruler deeply devoted to the well-being of his subjects: magnanimous and just, he constantly favours peaceful solutions over war. Moving from the universal principles of good government illustrated by these anecdotes to what may be called their historical "traceability", the analysis takes an interesting turn. In this respect, it should first be noted that only two of these anecdotes name historical characters other than the Habsburg. Interestingly enough, both of them pertain to the Iberian union that followed the death of the Portuguese cardinal-king Dom Henrique (ruled 1578-1580) in 1580.

The shortest one narrates how Philip II gained sovereignty over Portugal through the decision of an assembly (arish)_probably a reference to the Cortes of Tomar of 1581 - and how, fearing resistance from his new subjects, he entrusted the Duke of Alba (d. 1587) with taking over the kingdom. To such a request, the latter replied that if he could easily bring the kingdom and its inhabitants to submission, the conquest of their hearts was beyond his capacity, and eventually rested with the monarch himself. His words met with Philip II's approbation who, after the effective conquest of Portugal, decided to visit his new possessions personally: there, he quickly won the affection of his subjects through his benevolence. While the distortion of historical events is here minimal-the Cortes of Tomar did not precede but follow the Spanish demonstration of force-it grows out of proportion 
in the second anecdote referring to the Iberian union. This focuses on Martim Gonçalves da Câmara (1539-1613) who receives here unconditional praise as the faithful minister of two successive Portuguese monarchs, as well as Philip II of Spain after Portugal had come into his possession. Although neither of the Portuguese kings is named, the identity of who Xavier had in mind leaves little doubt. The first, after whose death a very young monarch is said to have ascended the throne, can only be Dom João III (ruled 1521-1557). As to his heir, it is of course the ill-fated Dom Sebastião whose personal reign and demise are duly but very briefly mentioned. Nothing, however, is said of his successor Dom Henrique, Xavier jumping directly to Philip II. Like his Portuguese predecessors, the latter decided to entrust Martim Gonçalves with the affairs of the kingdom, but only after a thorough investigation had convinced him of the man's exceptional qualities and probity.

Such a narrative raises, however, a number of issues when compared to what is known otherwise of the figure of Martim Gonçalves da Câmara, for, if he did indeed wield enormous power and influence during the first part of Dom Sebastião's reign, he was disgraced by that same monarch in 1576. In addition, he is not known to have played any significant political role under Dom João III nor under Philip II. On the contrary: dated April 1580, a letter by Cristóvão de Moura (1538-1613), Philip's agent in Portugal, describes him as one of the king of Spain's worst enemies (Paiva 2006: 14-15). One is therefore left to wonder why Xavier chose to inflate Martim Gonçalves's profile to the point of making it necessary to revise the latter's career so extensively. True, Martim was himself a secular priest closely connected with the Jesuit milieu (on his brother Luís Gonçalves, a Jesuit who served Dom Sebastião as tutor and confessor, see Alden 1996: 81-84) but, as this piece of information surfaces nowhere in the $\bar{A} d \bar{a} b$, it is hard to believe that Xavier's distortion was meant to highlight the Jesuits' qualities as kingly advisers. Be that as it may, the treatment Martim Gonçalves received at the hands of Xavier is very instructive where the transmission of Western political history to the Mughal court is concerned. Indeed, it shows that the transformations entailed by such a process did not solely derive from the requirements of translation but may have followed a different logic that is sometimes difficult to grasp.

All in all, Xavier's mirror for princes was hardly the place for the Mughals to find a discussion about the latest developments of Western political history and thinking; it was unlikely, therefore, to act as a source of inspiration in this domain. Besides, the scarcity of the surviving manuscripts as well as their exclusively European location (see supra: n. 1) point to the rather limited success of the $\bar{A} d \bar{a} b$-us-saltanat in India, particularly as compared to the Samarat-ul-faläsifa. On the basis of the present survey, and pending further research on the subject, it may therefore be safe to conclude that early modern Europe was not among the role models the Mughals referred to in matters of state building or technologies of governance. Why exactly such was not the case is, however, a question that remains to be thoroughly examined. 


\section{Mughal India and Safavid Iran: Political Transfers in Muslim Asia}

In this respect, and in contrast to the situation described above, one stands on firmer ground when moving into what I have called the Asian-Islamicate ecumene. As indicated in the introduction, recent scholarship has called attention to the circulation of elites and their contribution to the dissemination of political models within this space. If a number of studies have brought to light interesting cases of sometimes multilateral ideological influences, fewer have addressed the question of governmental technologies as part of politico-cultural transfers. The second part of the present essay will focus on such a case of transfer through the analysis of Mughal emulation of the Safavid mercantilist policy inaugurated by Shāh Abbās I (ruled 1587-1629). ${ }^{5}$

Before presenting the main characteristics of the latter, it is important to note the existence among the Tâjik elites of Iran of a long tradition combining political and commercial participation and embodied by the figure of the tājir (pl. tujjār) or merchant (Calmard 1988). From the fifteenth century onwards, a number of them chose to settle in South and South-East Asia, sometimes responding to the invitation of newly-created dynasties. This holds particularly true for the Deccan, where Bahmanid sultans (1387-1489) and their successors in Bijapur, Ahmadnagar, and Golconda encouraged the migration of Iranians to their territories and gave pride of place to individuals with dual administrative and commercial expertise (Subrahmanyam 1992). For all that, it was not to the Täjik tujjār-among whom many Sayyids were also to be found — that Shāh 'Abbās turned for the implementation of his centralising reforms, of which the new mercantilist orientation was only a part. On the contrary, he treated them with greater hostility than his predecessors, being suspicious of the socio-religious prestige of the Sayyids, and, more generally, of their propensity to invest both in land property and in commercial activities. The Safavid therefore chose to rely on two groups - a corps of slaves and the Armenian merchant community_who were more amenable to his wishes than the Tājik merchant-administrators. The Armenian support was especially important for the development of 'Abbās' new commercial policy which aimed primarily at increasing the silver reserves of the state. ${ }^{6}$ In order to do so, the monarch resorted to a number of measures, including an import-substitution policy for cotton cloth, a ban on gold and silver exports, and, most famously, the instauration of a state monopoly on silk exports (1619). Silk was Iran's most valuable export product and the newly created monopoly guaranteed the state the major part of the benefits accruing from its trade by compelling foreign merchants-mostly representatives of the East India Company (EIC) and the Verenigde Oostindische Compagnie (VOC) — to deal

\footnotetext{
${ }^{5}$ For an extended version of this point and a larger discussion of reciprocal Mughal and Safavid influences, see Lefèvre (2010).

${ }^{6}$ The following presentation of 'Abbās's mercantilist policy is based on Matthee (1999: 61-118).
} 
exclusively with state-appointed intermediaries. Besides, 'Abbās worked hard to provide Iran with a commercial outlet that would be safe from Ottoman and Portuguese appetites. To this end, he simultaneously explored the possibilities offered by the Northern land route (via Russia) and the Southern maritime axis (via the Persian Gulf). Thanks to the expulsion of the Portuguese from Hormuz in 1622 , the latter solution finally prevailed: the port of Bandar 'Abbās was founded on the site of ancient Gombroon and soon became a major commercial hub.

In contrast to the mercantilist model elaborated by Shāh 'Abbās, Mughal participation in trade appears far more limited at first sight. Just as their Afghan predecessors and their Uzbek and Safavid contemporaries, Akbar and Jahāngīr certainly considered the protection of merchants and the maintenance of a decent road network a part of their kingly duty. Besides, trade represented a significant source of income for the state, especially after the conquest of the two maritime sultanates of Gujarat and Bengal in the 1570s, even though the revenues deriving from this lagged behind those accruing from agricultural production. Even so, beyond this traditional relationship of protection and taxation, a number of elements point to the greater involvement of the Mughals in commercial activities from the first quarter of the seventeenth century onwards.

The first element is undoubtedly the growing participation of the imperial family and the Mughal elite in maritime trade. This is borne out by a series of documents such as the registers of the Estado da Índia (Flores 2005: 261-264), the correspondence of English and Dutch merchants with the EIC and the VOC (Chandra 1959: 93-94) and a collection of Mughal administrative papers concerning the port of Surat (Hasan 1989-1990; Moosvi 1990). All testify to the fact that Mughal monarchs and members of their family (including women) were the owners of ships conveying their goods (textiles, indigo, tobacco) to the great ports of the Persian Gulf, the Red Sea and South-East Asia. As shown by the nature of the evidence gathered here, the mercantilist evolution of the dynasty failed, however, to be integrated on the ideological level. The same holds true for administrative elites who, from the 1600s on, increasingly engaged in sea trade. The more active among them were the officials posted in the maritime provinces of the empire, such as Gujarat (Flores 2011; Hasan 2004: 31-51), along with the many Iranian migrants who gained predominance in the Mughal nobility precisely around this time. Particularly significant is, in this last respect, a remark by the Dutch factor Francisco Pelsaert, who blamed the Iranians as much for trusting the higher levels of Mughal administration as for their excessive intervention in the economy (Pelsaert 1957: 92).

The successive stages of the Iranian rise to power in the Mughal state apparatus are well known: initiated by Humāyūn (ruled 1530-1540; 1555-1556), vigorously pursued by Akbar, the recruitment of Iranians further intensified in the time of Jahāngīr, during whose reign they achieved first rank in the nobility in respect both to numbers and positions. Symbolised by the ascendancy of Nūr Jahān's family (the favourite queen, herself of Iranian origin), the migration flow continued unabated throughout the seventeenth century even though, from the 1650s on, Iranians increasingly had to compete with other groups (Indian Muslims, Rājpūts) for 
state patronage. In their attempt to explain Mughal "Iranophily", historians have generally emphasised the push factors lying behind it, including Safavid religious intolerance and the limited career prospects offered by Iran as compared to India. While it cannot be denied that such factors did play a substantial role, this line of explanation is marred by its portraying of the Mughals as totally passive in the process. As rightly suggested by Sanjay Subrahmanyam (1992), the profile of those Iranians who reached the highest levels of Mughal state apparatus, as well as the nature of the positions they held, rather point to the fact that Indian monarchs valued these individuals for very specific competences.

The case of Nūr Jahān's family appears particularly significant in this respect (Habib 1969). Of her grandfather Khwāja Muhammad Sharīf, a Tājik from Tehran, we know that he held an important position in the Safavid fiscal administration under Shāh Ṭahmāsp (ruled 1524-1576) and was associated with the renowned and powerful family of Āqā Muḥammad Dawatdār through matrimonial alliance. His son I'timād-ud-daula chose to settle in India, where his expertise in fiscal matters enabled him to hold the combined offices of wazir and wakil from 1611 until his death in 1621. These same competences were transmitted to his son Āṣaf Khān who, like his father, is praised in contemporary literature for his ability in the fiscal domain; more importantly, he inherited from his father the position of wakill, which he likewise held until his death in 1641. As a matter of fact, statistical studies have shown that the highest offices in Mughal fiscal administration became an Iranian preserve from Jahāngīr's reign on (Ali 1985). Āṣaf Khān is also the first member of the family whose commercial activities are known in detail, even though the profile of Khwāja Muḥammad Sharīf and his connections with Āqā Muḥammad Dawatdār leads one to believe that trade was already part of the portfolio of familial activities back in Iran. Whatever the case may be, the family's involvement in commerce only grew stronger during the second half of the seventeenth century, as shown by Āṣaf Khān's and his son Shayista Khān's strong participation in the trade of the Bay of Bengal (Prakash 1985).

Before concluding on this point, it is worth pausing briefly to consider another biography, whose complexity is all the more illuminating. Mīr Jumla Ișfahānī hailed from one of the Sayyid clans of Ispahan, whose diversified interests in land property, manufacturing, and commercial activities are otherwise well known. He left Iran at the beginning of the seventeenth century and settled in Golconda where, according to the memoirs of Jahāngīr, he was, for ten years, the factotum of Muhammad Qulī Quṭb Shāh (ruled 1580-1612) and the centre of the affairs of the state (Jahāngīr 1999: 258). In 1613, his falling out with the next sultan drove him out of Golconda, and it is only after he had failed to attract the patronage of the neighbouring kingdom of Bijapur that he resolved to go back to Iran. The reasons for this reluctance are made clear by the treatment he received at the court of Shāh 'Abbās. After having tried for a while to exchange a part of the immense wealth he had acquired in India (through his fiscal duties and his likely participation in the lucrative trade of Masulipatnam) for a high position in Safavid administration, Mīr Jumla understood that the Shāh would concede no political participation to him and, in 1618, he therefore decided to leave yet again for the subcontinent 
(Bhakkarī 2003: 72). At the Mughal court, the Mīr actually obtained what the Safavid had denied him and henceforth held a series of high positions in the imperial administration until his death in 1637 (Ali 1985: 128, 141). The case of Mīr Jumla Ișfahānī vividly illustrates how the Iranian merchant-administrators were pushed into the background in Safavid times, driving many of them on to the road to India as a result. Besides, his successful career under Jahāngīr and Shāh Jahān demonstrates the degree to which the Mughals valued the Iranian elites, who combined administrative and commercial expertise. That men such as Mīr Jumla, I'timād-ud-daula, and so many others were also natural vehicles for the diffusion of Shāh 'Abbās' new commercial policy in Mughal territories is beyond doubt. The growing participation of the imperial family and the Mughal elite in maritime trade and the Iranian hegemony in the politico-economic sphere are not, however, the only elements hinting at the Mughals' attraction towards state mercantilism. It is also borne out by some specific directions of Mughal expansion, as well as by the hardening of the dynasty's attitude toward European trade companies.

Contrary to received wisdom, Jahāngīr's reign did not coincide with the complete cessation of the conquest process (re)initiated by Akbar: the new monarch succeeded in subjecting Rājpūt Mewar, kept the Deccani sultanates under continuous pressure, and, more importantly for the present purpose, pursued Mughal expansion into the southern and eastern fringes of Bengal. The main motivation behind this last operation was essentially commercial, the Mughals aiming at seizing Bengal's two principal ports-Hughli to the west and Chittagong to the east-which were then under the control of Portuguese merchants and the Magh dynasty of Arakan, respectively. It is true that nothing came of these expeditions at the time. However, Jahāngīr's efforts were continued by his successors and finally proved successful; Hughli and Chittagong fell to the Mughals in 1632 and 1666 respectively, henceforth providing the dynasty with privileged access to the Bay of Bengal and its lucrative trade.

Jahāngīr not only pursued an aggressive policy on the eastern margins of the empire, he also took a harder line on the European presence on the western coast. The first open conflict broke out in 1613 with the seizure and destruction by the Portuguese of a ship from Surat that was bringing a valuable cargo back from Jeddah, a cargo in which the emperor's mother had an important interest (Flores 2005: 251-261). The scale of Jahāngīr's reaction-all the Europeans living in the empire were put under arrest and had their goods seized-shows that the Mughals were less and less ready to accept European control of sea trade, and indicates, by the same token, their growing interest in this activity. A period of "contained conflict" succeeded the crisis of 1613-1615, which lasted until the end of the reign and saw the Portuguese progressively lose ground against the Mughals' increasing pressure. In this respect, Jahāngīr's 1617-1618 trip to Gujarat appears particularly significant, because of its likely connection with the new commercial policy that was taking shape at the time. During his short stay in Cambay, the monarch actually publicised his willingness to promote traffic between the western coast of the empire and the Red Sea, and to turn Cambay into the most attractive harbour of the whole western Indian Ocean, thanks to the fiscal reforms he intended 
to introduce there. That he took the opportunity during his stay in Gujarat to assign the government of the province to his son Shāh Jahān is also no coincidence: he thereby made sure that imperial authority would be felt more strongly in the future, especially vis-à-vis the Europeans (Jahāngīr 1999: 241, 244).

In this, as in many other cases, Shāh Jahān proved to be an excellent choice. The prince was himself actively involved in Gujarātī trade, and Portuguese archives indicate that he indeed took a harder line against the Estado da Índia (Flores 2005: 262-264). The Portuguese were not, however, the only Westerners to feel the bitter taste of his formidable gift for negotiation, his dealings with the English factors of Surat testifying to his expert use of the carrot and stick method (Faruqui 2002: 187-189). With the support of his father, Shāh Jahān succeeded in establishing, within the context of Gujarat, a steadfast commercial policy whose aim was to develop Mughal interests in international trade, liberate them from Portuguese control and, more generally, to protect them from European appetites. In many respects, the government of the richest province of the empire may thus be said to have been the laboratory where the prince elaborated and put to the test the mercantilist policy he was to develop as king. For, of all Mughal monarchs, Shāh Jahān was certainly the one most deeply involved in maritime trade. Besides, Iranians continued to be massively recruited under his rule and to trust the higher levels of the fiscal apparatus. Last but not least, Mughal mercantilist tendencies grew even stronger at his instigation, as shown, for instance, by the expulsion of the Portuguese from Hughli in 1632, or the attempts to institute royal monopolies on commodities such as indigo, lime, or saltpetre (Chandra 1959: 94-95).

The commercial policy of the dynasty was not, however, the only sphere to bear the imprint of the processes of competition and imitation that informed the relations of Mughal India with the contemporary polities of Muslim Asia throughout the early modern period. Reciprocal influences were also of tremendous importance where state ideology was concerned. As has been argued elsewhere (e.g. Lefèvre 2010; Moin 2010), this holds particularly true for Mughals and Safavids during the seventeenth century, but other examples are not hard to find. To cite but one, Paul Wormser (2009) has recently built on the earlier insight of Denys Lombard to demonstrate how the sultans of Aceh successively turned to Ottoman and Mughal models to legitimise their power and elaborate a sophisticated royal ideology. As far as political ideas and instruments are concerned, there is, then, no denying that the transfers that took place within the Asian-Islamicate ecumene far exceeded the exchanges between Europe and Muslim Asia in early modern times. This is, of course, in sharp contrast with the situation that was to prevail with the advent of European domination in the region from the eighteenth century on. 


\section{Bibliography}

'Abd-us-Sattār b. Qāsim Lāhaurī. 2006. Majālis-i Jahāngīrī, ed. A. Naushahi and M. Nizami. Tehran: Miras-i Maktub.

Abd-us-Sattār b. Qāsim Lāhaurī. Samarat-ul-falāsifa. British Library, London, MS. Or. 5893.

Alam, Muzaffar and Sanjay Subrahmanyam. 2009. "Frank disputations: Catholics and Muslims in the court of Jahangir (1608-11)." Indian Economic and Social History Review 46/4: 457-511.

Alden, Dauril. 1996. The Making of an Enterprise. The Society of Jesus in Portugal, its Empire and Beyond, 1540-1750. Stanford: Stanford University Press.

al-Himyarī. 1938. Kitāb al-Rawz al-mi'țār fì khabar al-aqtārr. Partial ed. and tr. E. Lévi-Provençal, La péninsule ibérique au Moyen Age d'après le Kitāb al-Rawd al-Mìțär fì habar al-akțār. Texte arabe des notices relatives à l'Espagne, au Portugal et au Sud-Ouest de la France. Leiden: E. J. Brill.

Ali, Muhammad Athar. 1985. The Apparatus of Empire. Awards of Ranks, Offices and Titles to the Mughal Nobility, 1574-1658. Delhi: Oxford University Press.

Ali, Muhammad Athar. 1992. "Political Structures of the Islamic Orient in the Sixteenth and Seventeenth Centuries." In Medieval India 1. Researches in the History of India, 1200-1750, ed. I. Habib. Delhi: Oxford University Press: 129-140.

Bailey, Gauvin A. 1998. The Jesuits and the Grand Mogul: Renaissance Art at the Imperial Court of India, 1580-1630. Washington D. C.: Freer Gallery of Art, Arthur M. Sackler Gallery \& Smithsonian Institution.

Bailey, Gauvin A. 2000. "The Truth-Showing Mirror: Jesuit Catechism and the Arts in Mughal India." In The Jesuits. Cultures, Sciences and the Arts, ed. J. W. O'Malley et al. TorontoBuffalo-London: University of Toronto Press: 380-401.

Bāqir Khān, Muhammad (Najm-i Sānī). 1989. Maưizia-i Jahāngīrī. Ed. and tr. S. S. Alvi, Advice on the Art of Governance: An Indo-Islamic Mirror for Princes of Muhammad Bāqir Najm-i Sānī. Albany: State University of New York Press.

Bhākkarī, Shaikh Farīd. 2003. Zakhīrat-ul-khawanīn. Tr. Z. A. Desai, Nobility under the Great Mughals. Based on the Dhäkīratul Khawanin of Shaikh Farìd Bhakkari. Delhi: Sundeep Prakashan.

Calmard, Jean. 1988. "Les marchands iraniens: formation et montée d'un groupe de pression, $16^{\mathrm{e}}-19^{\mathrm{e}}$ siècles." In Marchands et hommes d'affaires asiatiques dans l'Océan Indien et la Mer de Chine, $13^{e}-20^{e}$ siècles, ed. J. Aubin and D. Lombard. Paris: Éditions de l'EHESS: 91-107.

Camps, Arnulf. 1957. Jerome Xavier, S.J. and the Muslims of the Mogul Empire: Controversial and missionary activities. Schöneck-Beckenried: Nouvelle Revue de Science Missionnaire.

Chandra, Satish. 1959. "Commercial Activities of the Mughal Emperors during the $17^{\text {th }}$ century." Bengal Past and Present 78/2: 92-97.

Dale, Stephen Frederic. 1998. "The Legacy of the Timurids." Journal of the Royal Asiatic Society, Series 3 8/1: 43-58.

Das Gupta, Ashin. 1979. Indian merchants and the decline of Surat, c. 1700-1750. Wiesbaden: Steiner.

Digby, Simon. 1999. "Beyond the Ocean: Perceptions of Overseas in Indo-Persian Sources of the Mughal Period." Studies in History 14/2: 247-259.

Farooqi, Naimur R. 1989. Mughal-Ottoman Relations: A Study of Political and Diplomatical Relations between Mughal India and the Ottoman Empire, 1556-1748. Delhi: Idarah-i Adabiyat-i Delli.

Faruqui, Munis Daniyal. 2002. Princes and Power in the Mughal Empire, 1569-1657. Ph.D.: Duke University.

Flores, Jorge. 2005. "Firingistan" e "Hindustan". O Estado da Índia e os confines meridionais do Imperio Mogol (1572-1636). Ph.D.: Universidade Nova de Lisboa.

Flores, Jorge. 2011. "The Sea and the World of the Mutasaddi: A Profile of port officials from Mughal Gujarat (c. 1600-1650)." Journal of the Royal Asiatic Society, Series 3 21/1: 55-71. 
Habib, Irfan. 1969. "The Family of Nur Jahan during Jahangir's Reign: A Political Study." In Medieval India. A Miscellany. Vol. 1. Mumbai: Asia Publishing House: 74-95.

Habib, Irfan. 1980. "Cartography in Mughal India." In Medieval India. A Miscellany. Vol. 4. Mumbai: Asia Publishing House: 122-134.

Hasan, Farhat. 1989-1990. "Mughal Officials at Surat and their Relations with the English and Dutch Merchants: Based on a Collection of Persian Documents of the Reigns of Jahangir and Shah Jahan." In Proceedings of the Indian History Congress, 50 ${ }^{\text {th }}$ Session. Delhi: Indian History Congress: 284-293.

Hasan, Farhat. 2004. State and Locality in Mughal India. Power Relations in Western India, c. 1572-1730. Cambridge: Cambridge University Press.

Islam, Riazul. 1970. Indo-Persian Relations: a Study of the Political and Diplomatic Relations between the Mughal Empire and Iran. Tehran: Iranian Culture Foundation.

Jahāngīr, Nūr-ud-dīn Muhammad. 1999. Jahāngīr Nāma. Tr. W. M. Thackston, Jahāngīr Nāma. Memoirs of Jahāngīr, Emperor of India. Washington D. C. and New York: Freer Gallery of Art and Arthur M. Sackler Gallery, Smithsonian Institution \& Oxford University Press.

Koch, Ebba. 1997. "The Hierarchical Principles of Shah-Jahani Painting." In King of the World: The Padshahnama: An Imperial Mughal Manuscript from the Royal Library, Windsor Castle, ed. M. C. Beach, E. Koch and W. M. Thackston. London and Washington D. C.: Azimuth Editions and Sackler Gallery, Smithsonian Institution: 130-143.

Koch, Ebba. 2001. Mughal Art and Imperial Ideology. Collected Essays. Delhi: Oxford University Press.

Koch, Ebba. 2009. "Jahangir as Francis Bacon's Ideal of the King as an Observer and Investigator of Nature." Journal of the Royal Asiatic Society, Series 3 19/3: 293-338.

Lefèvre, Corinne. 2010. "Jahāngīr et son frère S̄āh 'Abbās : compétition et circulation entre deux puissances de l'Asie musulmane de la première modernité." In Muslim Cultures in the Indo-Iranian World during the Early-Modern and Modern Periods, ed. D. Hermann and F. Speziale. Berlin and Tehran: Klaus Schwarz and IFRI: 23-56.

Maclagan, Edward Douglas. 1932. The Jesuits and the Great Mogul. London: Burn Oates \& Washbourne Ltd.

Matthee, Rudolph P. 1999. The Politics of Trade in Safavid Iran. Silk for Silver, 1600-1730. Cambridge: Cambridge University Press.

Moin, Ahmed Azfar. 2010. Islam and the Millennium: Sacred Kingship and Popular Imagination in Early Modern India and Iran. Ph.D.: University of Michigan.

Momigliano, Arnaldo. 1982. "The Origins of Universal History." Annali della Scuola Normale Superiore di Pisa. Classe di lettere e filosofia, 3rd Series 12/2: 533-560.

Moosvi, Shireen. 1990. "Mughal Shipping at Surat in the First Half of the Seventeenth Century." In Proceedings of the Indian History Congress, $51^{\text {st }}$ Session. Delhi: Indian History Congress: 308-320.

Moosvi, Shireen. 2002. "Sharing the "Asiatic Mode"? India and Iran.” In A Shared Heritage. The Growth of Civilization in India and Iran, ed. I. Habib. Delhi: Tulika Books: 177-188.

Necipoğlu, Gülru. 1993. "Framing the Gaze in Ottoman, Safavid and Mughal Palaces." In Pre-Modern Islamic Palaces (Ars Orientalis 23), ed. G. Necipoğlu. Ann Arbor: University of Oklahoma Press: 303-342.

Paiva, José Pedro. 2006. "Bishops and Politics: The Portuguese Episcopacy During the Dynastic Crisis of 1580." E-Journal of Portuguese Studies 4/2: 1-19.

Paulmier-Foucart, Monique (with the collaboration of M.-C. Duchenne). 2004. Vincent Beauvais et le Grand miroir du monde. Turnhout: Brepols Publishers NV.

Pearson, Michael N. 1987. The Portuguese in India (The New Cambridge History of India I/1). Cambridge: Cambridge University Press.

Pelsaert, Francisco. 1957. A Contemporary Dutch Chronicle of Mughal India, ed. and tr. B. Narain and S. R. Sharma. Kolkata: Susil Gupta (India) Limited.

Picard, Christophe. 2003. "Le passé antique et l'histoire d'al-Andalus chez les auteurs arabes." Pallas : revue d'études antiques 63: 97-106.

Prakash, Om. 1985. The Dutch East India Company and the Economy of Bengal, 1630-1720. Delhi: Oxford University Press. 
Qaisar, Ahsan Jan. 1982. The Indian Response to European Technology and Culture (A.D. 1498-1707). Delhi: Oxford University Press.

Ramaswamy, Sumathi. 2007. "Conceit of the Globe in Mughal Visual Practice." Comparative Studies in History and Society 49/4: 751-782.

Sidarus, Adel. 2010. "O Espelho de Príncipes de Jerónimo Xavier SJ dedicado ao Imperador Mogol (1609)." In Caminhos Cruzados em História e Antropologia. Ensaios de Homenagem a Jill Dias, ed. P. J. Havik, C. Saraiva and J. A. Tavim. Lisbon: Imprensa de Ciências Sociais: 37-50.

Subrahmanyam, Sanjay. 1992. "Iranians abroad: Intra-Asian Elite Migration and Early Modern State Formation.” Journal of Asian Studies 51/2: 340-363.

Subrahmanyam, Sanjay. 2005. "Taking Stock of the Franks: South Asian Views of Europeans and Europe, 1500-1800.” Indian Economic and Social History Review 62/1: 69-100.

Teltscher, Kate. 1995. India Inscribed. European and British Writing on India (1600-1800). Delhi: Oxford University Press.

Terry, Edward. 1777. A Voyage to East-India (1 ${ }^{\text {st }}$ ed., 1655). London: J. Wilkie.

Walker, James Bernard. 1933. The "Chronicles" of Saint Antoninus. Washington, D. C.: The Catholic University of America.

Wormser, Paul. 2009. “Un modèle moghol à Aceh au XVII siècle?”. Archipel 77: 69-82.

Xavier, Jerónimo. Ādāb-us-salțanat. School of Oriental and African Studies, London, MS. 7030. 